\title{
Lambs Fed Diets Containing By-Product from Coconut Processing: Histomorphometry Characteristics in the Digestive and Renal Systems
}

\section{Felipe José Santos da Silva}

Paraiba Federal University: Universidade Federal da Paraiba

Dorgival Morais de Lima Júnior

Federal University of Alagoas: Universidade Federal de Alagoas

Ricardo Romão Guerra

Paraiba Federal University: Universidade Federal da Paraiba

Vitor Visintin Silva de Almeida

Federal University of Alagoas: Universidade Federal de Alagoas

Julimar do Sacramento Ribeiro

Federal University of Alagoas: Universidade Federal de Alagoas

Beatriz Dantas Oliveira Fernandes

Paraiba Federal University: Universidade Federal da Paraiba

\section{Anaiane Pereira Souza}

Universidade Federal do Sul e Sudeste do Pará: Universidade Federal do Sul e Sudeste do Para

Ariosvaldo Nunes de Medeiros ( $\nabla$ ariosvaldo.medeiros@academico.ufpb.br)

Paraiba Federal University: Universidade Federal da Paraiba https://orcid.org/0000-0002-1997-2649

\section{Research Article}

Keywords: alternative food, Cocos nucifera, fatty acids, intestinal health, oleaginous, ruminal papilla

Posted Date: January 10th, 2022

DOI: https://doi.org/10.21203/rs.3.rs-1199407/v1

License: (1) (1) This work is licensed under a Creative Commons Attribution 4.0 International License. Read Full License 


\section{Abstract}

This study aimed to evaluate the histological characteristics in the digestive and renal systems of lambs fed diets containing coconut by-product (CB). A total of 35 male lambs with an initial weight of $16.9 \pm$ $2.93 \mathrm{~kg}$ were distributed in a completely randomized design with five levels of CB in the diet $(0 ; 4.8 ; 9.6$; 14.4 and $19.2 \%$ in total dry matter). Samples of the liver, kidney, rumen, and intestine were histomorphometrically evaluated and the data were submitted to regression analysis, at a $5 \%$ error probability. The inclusion of CB linearly decreased the dry matter intake and caused a quadratic effect for the height of ruminal papillae, absorption area, epithelium thickness, as well as for average daily gain. The inclusion of CB linearly increased the mucous layer and reduced the submucosal layer, as well as promoted a decrease in goblet cells in the small intestine. The inclusion of BC did not influence hepatic glycogen, additionally, the histopathological examination did not reveal liver damage or congestion, vacuolization, and necrosis of the renal tissue. Therefore, our results indicate that $\mathrm{CB}$ can be included in lambs diet up to the level of $7.2 \%$ without causing changes in the histomorphometry characteristics of the gastrointestinal tract and changes in liver and kidney tissue that compromise animal performance.

\section{Introduction}

The use of agro-industrial by-products generated through fruit processing in tropical regions is a strategy to make animal production more efficient and minimize costs associated with food. The coconut tree (Cocos nucifera L.) is a widespread plant throughout the world; however, its commercial exploitation is predominantly present in the tropics (Foale and Harries, 2011; Nayar, 2017). The processing of this fruit generates a large amount of waste, such as the coconut processing by-product (CB), which is obtained by scraping the film from the solid endosperm.

The inclusion of CB can strategically be used to attend to the energy requirements of lambs because of its high lipids content, considering that supplying energy in form of lipids improves animal performance and reduces feed costs (NRC, 2007; Toral et al., 2009). On the other hand, the increase of lipids content in diets may impact the ruminal fermentation, providing morphological changes in the ruminal mucosa, and affecting animal performance (Barboza et al., 2019; Gallo et al., 2019).

Studies in rats demonstrate an association between increased lipid intake and kidney damage (Declèves et al., 2014; Jang et al., 2020). The effect of lipid intake in the liver was evaluated in sheep, where the lipid intake was related to an increase in liver mass, where the authors discussed the role of this organ on lipid metabolism (Medeiros et al., 2008; Moreno et al., 2011). However, there are no reports on the histopathological characterization of these organs in lambs fed with CB. Therefore, we hypothesize that the high levels of CB included in the diet may affect the histomorphometry in organs of lambs. In this sense, this study aimed to evaluate the histological characteristics in the digestive and renal systems of lambs fed diets containing CB.

\section{Material And Methods}


The study was conducted according to ethical standards and approved by the Animal Use Ethics Committee of the Federal University of Alagoas (License No. 01/2018). The trial was carried out in the Federal University of Alagoas - Campus Arapiraca, located in the municipality of Arapiraca, Alagoas, Brazil, located under the geographical coordinates $9^{\circ} 45^{\prime} 6^{\prime \prime} \mathrm{S}, 36^{\circ} 39^{\prime} 37^{\prime \prime} \mathrm{W}$, with an altitude of 280 meters. The climate is tropical with a dry season (Koppen classification).

Thirty-five undefined breed lambs, intact males, with a mean age of 4 months and body weight (BW) of $16.9 \pm 2.93 \mathrm{~kg}$ were used in this study. The experimental area was composed of individual stalls, with dimensions of $1.0 \mathrm{~m} \times 1.6 \mathrm{~m}$, with access to individual drinking fountains feeders. Before the beginning of the experiment, all animals were identified and submitted to the control of ectoparasites and endoparasites (Cydectin ${ }^{\circledR}$ ) and vaccinated against clostridiosis (Poli-Star).

The lambs were distributed in a completely randomized design, the diets consisted of five levels of CB ( 0 ; 4.8; 9.6; 14.4 and $19.2 \%$ ) in dry matter (DM), with seven animals for level. The experimental period lasted 86 days, comprising 15 of adaptation to diets and facilities, and 71 days of data collection. The diets were composed of bagasse of sugar cane, corn, soybean meal, and CB (Tables 1 and 2), and were formulated to meet the nutritional requirements of lambs weighing $22.5 \mathrm{~kg}$ of $\mathrm{BW}$, to an average daily gain of $200 \mathrm{~g}$, according to the NRC (2007). The roughage: concentrate ratio was 33:67. The DM intake (DMI) of each lamb was estimated based on the measurements of food and orts. Food was provided ad libitum twice a day, the orts of each animal were weighed daily, and the offer was adjusted based on measurements from the two previous days, allowing for orts of approximately $12 \%$. To measure the average daily gain (ADG) the lambs were weighed at the beginning and the end of the period. 
Table 1

Chemical composition of ingredients used in diets containing coconut by-products.

\begin{tabular}{|c|c|c|c|c|}
\hline Composition & $\begin{array}{l}\text { Sugar cane } \\
\text { bagasse }\end{array}$ & Corn & $\begin{array}{l}\text { Soybean } \\
\text { meal }\end{array}$ & $\begin{array}{l}\text { Coconut by- } \\
\text { product }\end{array}$ \\
\hline Dry matter ${ }^{1}$ & 688 & 886 & 887 & 942 \\
\hline Organic matter ${ }^{2}$ & 963 & 987 & 942 & 972 \\
\hline $\mathrm{Ash}^{2}$ & 37 & 13 & 58 & 28 \\
\hline Crude protein ${ }^{2}$ & 16 & 74 & 431 & 184 \\
\hline Ethereal extract ${ }^{2}$ & 8 & 58 & 40 & 394 \\
\hline Neutral detergent fiber ${ }^{2,3}$ & 791 & 139 & 123 & 255 \\
\hline Acid detergent fiber 2,3 & 524 & 24 & 71 & 113 \\
\hline Lignin $^{2}$ & 82 & 4 & 1 & 38 \\
\hline${ }_{3}^{\text {Non-fibrous carbohydrates }}{ }^{2}$ & 148 & 717 & 348 & 140 \\
\hline Total carbohydrates ${ }^{2}$ & 939 & 856 & 471 & 394 \\
\hline
\end{tabular}


Table 2

Proportion of ingredients and chemical-chemical composition of experimental diets containing coconut by-products.

\begin{tabular}{|c|c|c|c|c|c|}
\hline \multirow[t]{2}{*}{ Ingredients $^{2}$} & \multicolumn{5}{|c|}{ Inclusion of the coconut by-product (\%) } \\
\hline & 0 & 4.8 & 9.6 & 14.4 & 19.2 \\
\hline Sugar cane bagasse & 333 & 333 & 333 & 333 & 333 \\
\hline Coconut by-product & 0 & 48 & 96 & 144 & 192 \\
\hline Corn & 382 & 342 & 302 & 262 & 221 \\
\hline Soybean meal & 247 & 240 & 232 & 225 & 217 \\
\hline Calcitic limestone & 3 & 3 & 3 & 3 & 3 \\
\hline Urea & 10 & 10 & 10 & 10 & 10 \\
\hline Common salt & 16 & 16 & 16 & 16 & 16 \\
\hline Mineral salt & 10 & 10 & 10 & 10 & 10 \\
\hline \multirow[t]{2}{*}{ Total } & 1000 & 1000 & 1000 & 1000 & 1000 \\
\hline & \multicolumn{5}{|c|}{ Chemical Composition } \\
\hline Dry matter ${ }^{1}$ & 824 & 827 & 829 & 832 & 835 \\
\hline Organic matter ${ }^{2}$ & 941 & 940 & 940 & 940 & 939 \\
\hline $\mathrm{Ash}^{2}$ & 59 & 60 & 60 & 60 & 61 \\
\hline Crude protein ${ }^{2}$ & 167 & 169 & 172 & 174 & 177 \\
\hline Ethereal extract ${ }^{2}$ & 35 & 51 & 67 & 83 & 99 \\
\hline Neutral detergent fiber ${ }^{2,3}$ & 347 & 353 & 358 & 364 & 369 \\
\hline Acid detergent fiber ${ }^{2,3}$ & 201 & 205 & 209 & 213 & 217 \\
\hline Non-fibrous carbohydrates ${ }^{2,3}$ & 418 & 394 & 369 & 344 & 319 \\
\hline Total carbohydrates ${ }^{2}$ & 765 & 746 & 727 & 708 & 689 \\
\hline
\end{tabular}

At the end of the experimental period, the lambs were randomly distributed in a slaughter order and submitted to $16 \mathrm{~h}$ of fasting. At the time of slaughter, the lambs were weighted, desensitized by the penetrative percussive method with the aid of a captive dart pistol, suspended by the hind limbs by ropes, 
and bled by splitting the carotid arteries and jugular veins according to the humane slaughter rules of the Ministry of Agriculture, Livestock, and Supply (2000).

The animals were manually skinned manually according to the methodology of Cezar and Sousa (2007), the internal components of the pelvic, abdominal, and thoracic cavities were removed, and then fragments no larger than $0.5 \mathrm{~cm}^{3}$ of the organs were collected: liver (left lateral lobe) and kidney (cortical area), and fragments no larger than $1 \mathrm{~cm}$ from the organs: rumen (dorsal sac wall) and small intestine (middle portion of the duodenum), which were fixed in 10\% formaldehyde, and packed in identified containers. These fragments were removed from the same topographic portion in all lambs.

Histomorphometric and histopathological analyzes were performed at the Animal Histology Laboratory, of the Agricultural Sciences Center of the Federal University of Paraíba, and the histological processing was performed according to the methodology described by Barboza et al. (2019), Lima et al. (2019), and Silva et al. (2020a).

For liver and kidney, 6 photomicrographs per animal were digitized, totaling 42 samples per diet for each organ, using the $\times 40$ objective. In each of the photomicrographs, the observer looked for

histopathological changes in the components of the nephron (renal corpuscle, proximal twisted tubules, Henle loop, and distal twisted tubules) to check for possible kidney damage caused by the inclusion of $\mathrm{CB}$ in the diets.

The samples of ingredients and orts were pre-dried at $55^{\circ} \mathrm{C}$ for $72 \mathrm{~h}$, in a forced air circulation oven and ground in a knife mill, with pore sieves of $1 \mathrm{~mm}$ and $2 \mathrm{~mm}$. The determinations of DM (method AOAC 934.01), mineral matter (MM; method AOAC 942.05), crude protein (CP, method AOAC 954.01), ether extract (EE; method AOAC 920.39), and lignin (method AOAC 973.18) were carried out by the AOAC (2019). The neutral detergent fiber (NDF) and acid detergent fiber (ADF) were determined according to Mertens (2002). The NDF and ADF were corrected for ash and protein according to Licitra et al. (1996).

For the rumen and small intestine histomorphometry, the $\times 40$ objective was used. For the rumen variables: height of the papilla (from the base to the apex) and width of the papilla (in the middle region) 5 measurements were taken per lamb, totaling 35 samples per diet. For the thickness of the muscular layer, epithelial thickness, and epithelial keratinization, 7 measurements were made per lamb, totaling 49 samples per diet. For the duodenum variables: mucosal and submucosal layer thickness, 6 measurements were made per lamb, totaling 42 samples per diet. For the variables mentioned above, hematoxylin-eosin histological staining was used. For the measurement of the number of goblet cells in the duodenum in each animal, the number of goblet cells in $2000 \mu \mathrm{m}$ linear intestinal epithelium was counted, under the histochemical staining of periodic acid from Schiff (PAS), using 4 areas of $500 \mu \mathrm{m}$.

For statistical analysis, the data were submitted to regression analysis using (PROC REG) of SAS University Edition, and the regression analysis (linear and quadratic models) obtained was considered significant when $P<0.05$, with the models being chosen based on the values of the determination coefficients and biological behavior. 


\section{Results}

The inclusion of CB promoted a decrease in the DMI (Figure $1 ; P<0.05)$. A quadratic effect $(P<0.05)$ was observed for the ADG with a maximum value of $164.1 \mathrm{~g} /$ day estimated for the inclusion of $3.6 \%$ of $C B$. The variables related to rumen morphometry were influenced $(P<0.05)$ by the inclusion of $\mathrm{CB}$, except for the width of the ruminal papilla (Table 3). The inclusion of CB up to $19.2 \%$ of the diet resulted in a quadratic effect $(P<0.05)$ for epithelial thickness, epithelial keratinization, and papilla height and, also for the rumen absorption area. The rumen muscle layer thickness decreased linearly $(P<0.05)$ with the inclusion of $\mathrm{CB}$.

Table 3

Morphometric measurements of the ruminal mucosa of lambs fed diets containing coconut by-products

\begin{tabular}{|c|c|c|c|c|c|c|c|c|}
\hline \multirow[t]{2}{*}{ Variables } & \multicolumn{5}{|c|}{ Inclusion of the coconut by-product (\%) } & \multirow[t]{2}{*}{ SEM } & \multicolumn{2}{|l|}{ P-valor } \\
\hline & 0 & 4.8 & 9.6 & 14.4 & 19.2 & & $\mathbf{L}$ & $\mathbf{Q}$ \\
\hline $\begin{array}{l}\text { Papilla height. } \\
\mu \mathrm{m}\end{array}$ & 1182 & 1111 & 1111 & 892 & 708 & 35.2 & $<0.01$ & $<0.01$ \\
\hline $\begin{array}{l}\text { Papilla width. } \\
\mu \mathrm{m}\end{array}$ & 369 & 365 & 362 & 364 & 362 & 4.27 & 0.62 & 0.77 \\
\hline $\begin{array}{l}\text { Absorption area. } \\
\mu \mathrm{m}^{2}\end{array}$ & 437884 & 406335 & 402860 & 327898 & 258279 & 13868 & $<0.01$ & $<0.05^{2}$ \\
\hline $\begin{array}{l}\text { Epithelial } \\
\text { thickness.jm }\end{array}$ & 155.7 & 138.7 & 165.9 & 143.8 & 121.3 & 3.53 & $<0.01$ & $0.02^{3}$ \\
\hline $\begin{array}{l}\text { Muscle layer. } \\
\mu \mathrm{m}\end{array}$ & 1224.2 & 1106.7 & 1089.8 & 1014.2 & 991.4 & 39.8 & $<0.04^{4}$ & 0.69 \\
\hline $\begin{array}{l}\text { Epithelial } \\
\text { keratinization. } \\
\mu \mathrm{m}\end{array}$ & 38.7 & 29.6 & 26.2 & 24.0 & 20.0 & 1.23 & $<0.01$ & $0.04^{5}$ \\
\hline $\begin{array}{l}{ }^{1} Y=1170.8+2.2 \\
2.28 x-0.188 x^{2}(\end{array}$ & $0.58)$ & (1) & ( & 1 & $359.8 x^{2}$ & 0.5 & $3 y=11$ & $\begin{array}{l}+ \\
0.91)\end{array}$ \\
\hline
\end{tabular}

The inclusion of $\mathrm{CB}$ increased the growth of the mucous layer $(P<0.05)$ and reduced the submucosal layer $(P<0.05)$, as well as the goblet cells in the small intestine of lambs (Table 4$)$. The inclusion of $\mathrm{CB}$ did not influence hepatic glycogen, and histopathological examination did not reveal liver damage or congestion, vacuolization, and necrosis of the renal tissue. 
Table 4

Mean thickness of mucosa, submucosa and calyceal cells of the small intestine of lambs fed diets containing coconut by-product

\begin{tabular}{|c|c|c|c|c|c|c|c|c|}
\hline \multirow[t]{2}{*}{ Variables } & \multicolumn{5}{|c|}{ Inclusion of the coconut by-product (\%) } & \multirow[t]{2}{*}{ SEM } & \multicolumn{2}{|l|}{ P-valor } \\
\hline & 0 & 4.8 & 9.6 & 14.4 & 19.2 & & L & $\mathbf{Q}$ \\
\hline Mucosa. $\mu \mathrm{m}$ & 470.8 & 470.0 & 508.6 & 519.8 & 521.1 & 9.03 & $0.016^{1}$ & 0.75 \\
\hline Submucosa. $\mu \mathrm{m}$ & 1273.2 & 946.5 & 941.8 & 938.0 & 672.6 & 38.39 & $<0.001^{2}$ & 0.56 \\
\hline Goblet cells & 93.0 & 91.1 & 70.1 & 68.4 & 67.9 & 3.25 & $<0.001^{3}$ & 0.35 \\
\hline
\end{tabular}

\section{Discussion}

The histomorphometric characteristics of the rumen, intestine, kidneys, and liver of lambs fed with CB levels were assessed in the present study. Our results indicated that the intermediate levels of inclusion of CB in the diet of lambs do not alter the histomorphometric characteristics of the gastrointestinal tract and hepatic or renal changes, which could compromise the animal's performance.

The inclusion of $C B$ resulted in a quadratic effect for $A D G$, this result is possibly a consequence of the decrease in the DMI with the inclusion of $C B$ in the diet. The estimated inclusion of $7.2 \%$ of $C B$ in the diet sustained the same ADG when compared to conventional diets in tropical regions using corn and soybean meal, which suggests that the evaluated by-product is an alternative that can be used as a substitute for grains in low quantities.

The quadratic effect for ruminal papilla height and epithelium thickness was possibly caused by the decrease in $\mathrm{DMI}$ and non-fibrous carbohydrates by lambs fed with higher amounts of CB, which possibly reduced the fermentable substrates by the ruminal microorganisms and may cause less production of the short-chain fatty acids at higher levels of CB inclusion (Rezaei et al., 2014; Shi et al., 2020). This fact can be explained by the absorption of the short-chain fatty acids, which stimulates the epithelial metabolism of the rumen and induces the growth of the epithelium (Baldwin et al., 2004; Wang et al., 2009), with the development of the height of the papillae strongly influenced by concentrations propionate and butyrate, as demonstrated by Suárez et al. $(2006 a, b)$, when observing greater development of the rumen mucosa in calves that were fed diets that provided higher concentrations of propionate and butyrate in the rumen.

A difference of $4.9 \%(56.8 \mu \mathrm{m})$ was estimated between the height of the ruminal papillae for the inclusion levels of $0 \%$ and $7.2 \%$ of $C B$ in the diets, however, a more impressive decrease was observed in the papillae height, where the inclusion of $14.4 \%$ of CB promoted $18.1 \%$ of difference $(202.19 \mu \mathrm{m})$, compared to the inclusion of $7.2 \%$ of CB. Possibly, up to the $7.2 \%$ level of CB inclusion, the propionate produced through the fermentation of glycerol released by the hydrolysis of triglycerides in $\mathrm{CB}$ stimulated the development of the papillae, and thus, combined with the increased availability of lipids in the small 
intestine, sustained similar performance when CB was not included in the diet, even with the decrease of non-fibrous carbohydrates in the diet.

Maintaining the height of the ruminal papillae is an important physiological process because even with the decrease in $\mathrm{DMI}$, the quadratic effect found for the absorption area ensured that the products of rumen fermentation, which are important sources of energy for lambs, were absorbed and supply part of the lamb's energy requirements (Lesmeister et al., 2004). Since the NDF was constant between the levels evaluated, the decrease in the muscular layer of the rumen may be associated with an increase in the lipid content of the diets and a decrease in the DMI with the inclusion of $\mathrm{CB}$, which resulted in a reduction in peristalsis and an increase in the duration of digesta retention (Owens and Basalan, 2016). This is because the intake of diets rich in EE stimulates the release of cholecystokinin (CCK), which in turn acts by reducing the motility of the rumen and small intestine (Reidelberger, 1994), and causes less hypertrophy and hyperplasia of the smooth muscle fibers that make up the rumen, leading to less development of the muscle layer compared to the $0 \%$ level (Suárez et al., 2006b). In other studies, the lower development of the rumen muscle layer was also associated with decreased ruminal motility when there were changes in the chemical composition of the evaluated diets (Wang et al., 2009; Lima et al., 2019).

The quadratic effect observed for epithelial keratinization possibly reflects the decrease in the passage rate at the highest levels of $\mathrm{CB}$ inclusion, which induced a lower flow of the digest over the ruminal papillae, decreasing the abrasive effect on them, which led to a lower turnover rate cell in the outer layer of the epithelium, causing the keratin layer of the ruminal epithelium to decrease (Silva et al., 2020b). In the small intestine, the decrease in the passage rate possibly caused a linear decrease in the submucosal layer with the inclusion of $\mathrm{CB}$. In this layer are located the Brunner glands that secrete an alkaline mucus to neutralize the $\mathrm{pH}$ of the region, and to protect the mucosa of the duodenum against harmful agents (Verdiglione and Montesi, 2019). Possibly, a decrease in the passage rate through this organ led to a decrease of mucus produced, thus causing a decrease in these glands, and consequently reducing the thickness of this layer (Lang and Tansy, 1983).

The amount of goblet cells in the intestine is considered a parameter of intestinal health, being better with the increase of these glands (Bueno et al., 2012). These cells are responsible for the mucin production, mucus responsible for assisting in peristalsis, in the mechanical protection of the intestinal epithelium and acting against infectious agents of the intestinal mucosa, and being a component of the intestinal glycocalyx, which helps in the food digestion. The lower passage rate in the higher levels of inclusion of CB may have decreased the proliferation of these cells for reducing the need to protect the epithelium against abrasion caused by the passage of the digesta, and thus, lesser need for mucus production.

The increase in the inclusion levels of CB increased the energy density of the diets, and the lipids started to represent an important source of energy to supply the lamb's energy demand. This event is evident with the increase of the intestinal mucous layer. This morphological modification allows the greater digestive capacity of the small intestine since a greater thickness of the mucosa indicates a greater 
height of the intestinal villus, because of the energy content of the diet and decreased passage rate (Montanholi et al., 2013; Lima et al., 2018). Thus, there was a greater area of contact between villi and nutrients and favored digestion and absorption to its maximum extent (Van Soest, 1994; Yansari et al., 2004; Gabriel et al., 2008). Despite apparently pointing to an increase in metabolic efficiency, there was no increase in $A D G$ with the increased inclusion of $C B$, as there was a decrease of $65.3 \%$ in IDM between levels 0 and $19.2 \%$ of inclusion of $C B$.

The absence of liver and kidney damage in the lambs fed with CB may have occurred due to the absence of toxicological properties and anti-nutritional factors of the coconut (Lima et al., 2015). Based on this parameter, the inclusion of $C B$ in all levels evaluated herein did not damage the liver and kidneys of lambs.

Therefore, our results indicate that CB can be included in diets for lambs up to the level of $7.2 \%$ without causing changes in the histomorphometric characteristics of the gastrointestinal tract and changes in liver and kidney tissue that compromise animal performance.

\section{Declarations}

\section{Funding}

The authors would like to thank the Fundação de Amparo à Pesquisa do Estado de Alagoas (FAPEAL, process $n^{\circ}$ 60030000420/2017), and the Conselho Nacional de Pesquisa e Desenvolvimento Científico e Tecnológico (CNPq) for the doctoral scholarship.

\section{Competing interests}

The authors declare that they have no competing interests.

\section{Ethics approval}

The study was conducted according to ethical standards and approved by the Animal Use Ethics Committee of the Federal University of Alagoas (License No. 01/2018).

\section{Consent to participate}

Not applicable.

\section{Availability of data and material}

The dataset generated or analyzed during the current study are available from the corresponding author upon reasonable request.

\section{Author's contribution}


The study was designed by Felipe José Santos da Silva, Dorgival Morais de Lima Júnior and Ariosvaldo Nunes de Medeiros. Felipe José Santos da Silva collected data in the field and laboratory and wrote the first draft. Beatriz Dantas Oliveira and Anaiane Pereira Souza improved and corrected the manuscript. Ricardo Romão Guerra, Vitor Visintin Silva de Almeida and Julimar do Sacramento Ribeiro contributed to the study. All the authors discussed the results and commented on the manuscript.

\section{References}

1. AOAC, Association of official analytical chemists, 2019. Official Methods of Analysis, 21ed, AOAC, Gaithersburg, MD.

2. Baldwin, R.L., McLeod, K.R., Klotz, J.L., Heitmann, R.N., 2004. Rumen development, intestinal growth and hepatic metabolism in the pre-and postweaning ruminant, Journal of Dairy Science, $87,55-65$

3. Barboza, S.C.R., Oliveira, J.S., Carvalho Souza, M.T., Lima Júnior, D.M., Lima, H.B., Guerra, R.R., 2019. Ovines submitted to diets containing cassava foliage hay and spineless cactus forage: histological changes in the digestive and renal systems, Tropical Animal Health and Production, 51, 1689-1697

4. Bueno, R., Albuquerque, R., Murarolli, V. D. A., AYA, L. A. H., Raposo, R. S. e Bordin, R. A., 2012. Efeito da utilização de probiótico sobre o desempenho e morfologia intestinal de Codornas japonesas, Brazilian Journal Of Veterinary Research And Animal Science, 49, 111-115

5. Cezar, M.F., Sousa, W. H., 2007. Carcaças ovinas e caprinas- Obtenção, avaliação e classificação. Editora Agropecuária Tropical, Uberaba, MG

6. Declèves, A.E., Zolkipli, Z., Satriano, J., Wang, L., Nakayama, T., Rogac, M., Le, T.P., Nortier, J.L., Farquhar, M.G., Naviaux, R.K., Sharma, K., 2014. Regulation of lipid accumulation by AMK-Activated kinase in high fat diet-induced kidney injury, Kidney International, 85, 611-623

7. Foale, M., Harries, H., 2011. Farm and Forestry Production and Marketing Profile for Coconut (Cocos nucifera). In: Elevitch, C.R. (ed.), Specialty crops for Pacific Island Agroforestry, Permanent Agriculture Resources (PAR), Holualoa, Hawai'i

8. Gabriel, I., Mallet, S., Leconte, M., Travel, A., Lalles, J.P., 2008. Effects of whole wheat feeding on the development of the digestive tract of broiler chickens, Animal Feed Science and Technology, 142, $144-162$

9. Gallo, S.B., Brochado, T., Brochine, L., Passareli, D., Costa, S.F., Bueno, I.C. d. S., Balieiro, J.C. d. C., Franzolin Neto, R., Tedeschi, L.O., 2019. Effect of biosurfactant added in two different oil source diets on lamb performance and ruminal and blood parameters, Livestock Science, 226, 66-72

10. Jang, H.S., Noh, M.R., Jung, E.M., Kim, W.Y., Guda, C., Foster, K.W., Oupicky, D., Ferrer, F.A., Padanilam, B.J., 2020. Proximal tubule cyclophilin $D$ regulates fatty acid oxidation in cisplatin-induced acute kidney injury, Kidney International, 97, 327-339

11. Kottek, M., Grieser, J., Beck, C., Rudolf, B., Rubel, F., 2006. World map of the Köppen-Geiger climate classification updated, Meteorologische Zeitschrif, 15, 259-263 
12. Lang, I.M. and Tansy, M.F., 1983. Mechanisms of the secretory and motor responses of the Brunner's gland region of the intestines to duodenal acidification Pflügers Archiv European Journal of Physiology, 396, 115-120

13. Lesmeister, K.E., Tozer, P.R. and Heinrichs, A.J., 2004. Development and analysis of a rumen tissue sampling procedure Journal of Dairy Science, 87, 1336-1344

14. Licitra, G.; Hernandez, T. M.; Van Soest, P. J., 1996. Standardization of procedures for nitrogen fractionation of ruminant feeds. Animal Feed Science and Technology, v. 57, n. 4, p. 347-358.

15. Lima, E.B.C., Sousa, C.N.S., Meneses, L.N., Ximenes, N.C., Santos Júnior, M.A., Vasconcelos, G.S., Lima, N.B.C., Patrocínio, M.C.A., Macedo, D., Vasconcelos, S.M.M., 2015. Cocos nucifera (L.) (arecaceae): A phytochemical and pharmacological review, Brazilian Journal of Medical and Biological Research, 48, 953-964

16. Lima, A.G.V.O., Silva, T.M., Bezerra, L.R., Pereira, E.S., Barbosa, A.M., Ribeiro, R.D.X., Rocha, T.C., Trajano, J.S., Oliveira, R.L., 2018. Intake, digestibility, nitrogen balance, performance and carcass traits of Santa Ines lamb fed with sunflower cake from biodiesel production, Small Ruminant Research, 168, 19-24

17. Lima, T.J., Costa, R.G., de Medeiros, G.R., de Medeiros, A.N., Ribeiro, N.L., de Oliveira, J.S., Guerra, R.R. and de Carvalho, F.F.R., 2019. Ruminal and morphometric parameters of the rumen and intestines of sheep fed with increasing levels of spineless cactus (Nopalea cochenillifera Salm-Dyck), Tropical Animal Health and Production, 51, 363-368

18. MAPA - Ministério da Agricultura, Brasil, 2000. Instrução Normativa n³ 3, de 07 de janeiro de 2000. Regulamento técnico de métodos de insensibilização para o abate humanitário de animais de açougue. S. D. A. /M. A. A. Diário Oficial da União, Brasília, 24 jan. 2000, Seção 1, p.14-16.

19. Medeiros, G.R., Alves, K.S., Mattos, C.W., Saraiva, T.D.A., De Carvalho, F.F.R., Ferreira, M.D.A., Do Nascimento, J.F., 2008. Effect of concentrate levels on non carcass components of the Morada Nova hair sheep in feedlot, Revista Brasileira de Zootecnia, 37, 1063-1071

20. Mertens, D.R., 2002. Gravimetric determination of amylase-treated neutral detergent fiber in feeds with refluxing in beaker or crucibles: collaborative study. J. AOAC Int. 85 (6), 1217-1240.

21. Montanholi, Y., Fontoura, A., Swanson, K., Coomber, B., Yamashiro, S., Miller, S., 2013. Small intestine histomorphometry of beef cattle with divergent feed efficiency, Acta Veterinaria Scandinavica, 55, 1-6

22. Moreno, G.M.B., Sobrinho, A.G. da S., Leão, A.G., Perez, H.L., Loureiro, C.M.B., Pereira, G.T., 2011. Noncarcass components yield of lambs fed corn silage or sugar cane under two levels of concentrate, Revista Brasileira de Zootecnia, 40, 2878-2885

23. Nayar, N.M., 2017. The Coconut in the World. In: The Coconut, Elsevier, London

24. NRC - National Research Council, 2007. Nutrient requirements of small ruminants: sheep, goats, cervids, and new world camelids, National Academic Press, Washington, D.C.

25. Owens, F.N., Basalan, M., 2016. Ruminal fermentation. In: Millen, D., De Beni Arrigoni, M., Lauritano Pacheco, R. (Eds.), Rumenology, Springer, Cham 
26. Reidelberger, R.D., 1994. Cholecystokinin and Control of Food Intake. In: Symposium: New Research in the Physiology of Cholecystokinin: Nutrition Issues. American Institute of Nutrition.

27. Rezaei, J., Rouzbehan, Y., Fazaeli, H., Zahedifar, M., 2014. Effects of substituting amaranth silage for corn silage on intake, growth performance, diet digestibility, microbial protein, nitrogen retention and ruminal fermentation in fattening lambs, Animal Feed Science and Technology, 192, 29-38

28. Silva, K.B., Oliveira, J.S., Santos, E.M., Cartaxo, F.Q., Guerra, R.R., Souza, A.F.N., Muniz, A.C.S., 2020a. Ruminal and histological characteristics and nitrogen balance in lamb fed diets containing cactus as the only roughage, Tropical Animal Health and Production, 52, 637-645

29. Silva, T.G.P., Batista, Â.M.V., Guim, A., da Silva, V.A., de Carvalho, F.F.R., de Barros, M.E.G., de Sousa, D.R., da Silva, S.M.C., 2020b. Histomorphometric changes of the fore-stomach of lambs fed with diets containing spineless cactus genotypes resistant to Dactylopius sp., Tropical Animal Health and Production, 52, 1299-1307

30. Shi, F.Y., Guo, N., Degen, A.A., Niu, J.H., Wei, H.Y., Jing, X.P., Ding, L.M., Shang, Z.H., Long, R.J., 2020. Effects of level of feed intake and season on digestibility of dietary components, efficiency of microbial protein synthesis, rumen fermentation and ruminal microbiota in yaks, Animal Feed Science and Technology, 259, 114-359

31. Suárez, B.J., Van Reenen, C.G., Beldman, G., Van Delen, J., Dijkstra, J. and Gerrits, W.J.J., 2006a. Effects of supplementing concentrates differing in carbohydrate composition in veal calf diets: I. Animal performance and rumen fermentation characteristics Journal of Dairy Science, 89, 43654375

32. Suárez, B.J., Van Reenen, C.G., Gerrits, W.J.J., Stockhofe, N., Van Vuuren, A.M., Dijkstra, J., 2006b. Effects of supplementing concentrates differing in carbohydrate composition in veal calf diets: II. Rumen development, Journal of Dairy Science, 89, 4376-4386

33. Toral, P.G., Belenguer, A., Frutos, P., Hervás, G., 2009. Effect of the supplementation of a highconcentrate diet with sunflower and fish oils on ruminal fermentation in sheep, Small Ruminant Research, 81, 119-125

34. Wang, Y.H., Xu, M., Wang, F.N., Yu, Z.P., Yao, J.H., Zan, L.S., Yang, F.X., 2009. Effect of dietary starch on rumen and small intestine morphology and digesta $\mathrm{pH}$ in goats, Livestock Science, 122, 48- 52

35. Yansari, A.T., Valizadeh, R., Naserian, A., Christensen, D.A., Yu, P., Shahroodi, F.E., 2004. Effects of alfalfa particle size and specific gravity on chewing activity, digestibility, and performance of Holstein dairy cows, Journal of Dairy Science, 87, 3912-3924

36. Van Soest, P. J., 1994. Nutritional ecology of the ruminant, Ithaca: Cornell University

37. Verdiglione, R., Montesi, F., 2019. Ultrastructural investigation on bovine Brunner's glands, Translation Research in Anatomy, 15, 100-039

\section{Figures}




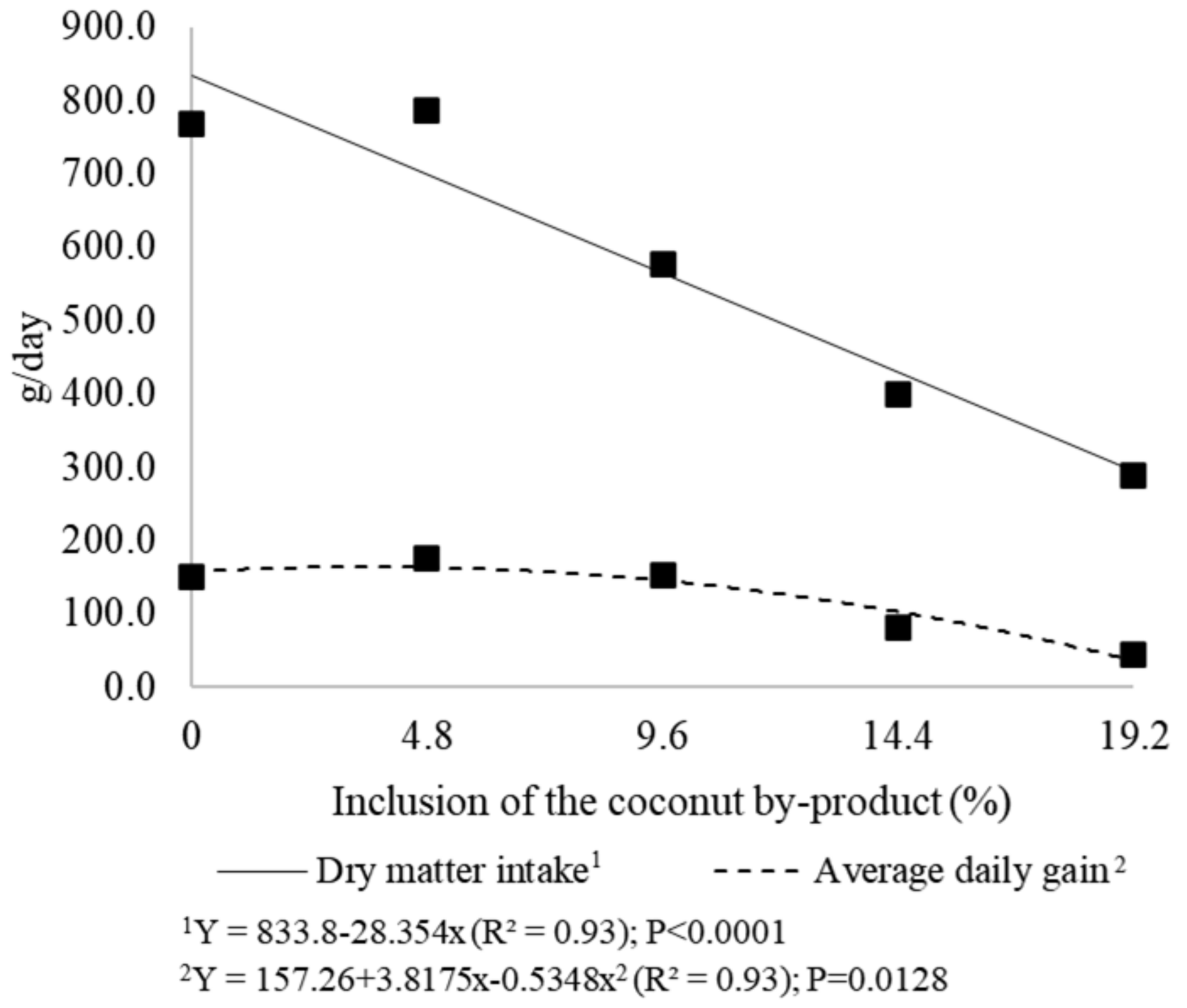

Figure 1

Dry matter intake and average daily gain ( $\mathrm{g} /$ day) of lambs fed diets containing coconut by-products 